\title{
Drought-related vulnerability and its policy implications in Hungary
}

\author{
Attila Buzási ${ }^{1} \cdot$ Tamás Pálvölgyi $^{1}$ - Diána Esses ${ }^{1}$ (iD \\ Received: 30 May 2020 / Accepted: 8 February 2021/ Published online: 8 April 2021 \\ (C) The Author(s) 2021
}

\begin{abstract}
Drought phenomena have been frequent in Hungarian history. One of the most important sectors in Hungary is agriculture, so the agricultural drought is a particularly important area to be examined. The purpose of the study is to determine how vulnerable each county (NUTS-3 regions) is to the expected effects of drought. The study provides an assessment framework of drought-related vulnerabilities and the preparedness of drought policies at the NUTS-3 level in Hungary. The drought-related vulnerability of NUTS-3 regions was determined by selected exposure, sensitivity, and adaptive capacity indicators. The calculation of drought vulnerability is based on the IPCC 2007 methodology, while the input data were derived from the National Adaptation Geo-information System online data platform and Hungarian agro-statistical data sources. An assessment framework of drought-related policy performance of NUTS-3-level climate change strategies was developed. The evaluation methodology is based on a specific scorecard of evaluation criteria related to the performance of the county's drought-related objectives and measures. According to the relationship between the county's drought-related vulnerability and policy performance, the counties were classified into four types. The main results show that several counties fail the target by overestimating the role of drought prevention, with little vulnerability index. In contrast, many counties are not adequately prepared for the impacts of drought, despite their high vulnerability index.
\end{abstract}

Keywords Vulnerability $\cdot$ Climate change $\cdot$ Drought policy $\cdot$ Hungary $\cdot$ Agriculture

\section{Introduction}

As the result of recent climate change and unsustainable land management, drought is one of the most significant climate-related challenges of the twenty-first century and is expected to

Diána Esses

esses.diana@eik.bme.hu

1 Department of Environmental Economics, Faculty of Economic and Social Sciences, Budapest University of Technology and Economics, Muegyetem rkp 3, Budapest H-1111, Hungary 
cause further severe damage by the end of the twenty-first century due to global warming. Everyone is aware of the phenomenon of drought; however, it can be interpreted in many ways, so there is no generally accepted definition of the effectiveness of drought-related adaptation activities.

The definition of drought can be divided into four types, depending on the area surveyed (Vogt and Somma, 2000):

- Meteorological drought: persistent and/or intense lack of rainfall. It can be characterized by a specific period during which the amount of precipitation is below the expected amount at a given location.

- Hydrological drought: a lack of water in both surface and underground aquifers.

- Agricultural drought: insufficient soil moisture relative to the needs of a given crop/plant. As a result, yields are reduced.

- Socioeconomic drought: water scarcity affects health, well-being, and quality of life, and the water supply needed to produce an economical product may be endangered. This may result in restrictions on drinking water supply, interruption, or restriction of ship transport (Vogt and Somma, 2000).

Spinoni et al. (2018a and b) suggest that climate change is also the result of unsustainable land management, which contributes to drought. By 2100, extreme events are likely to become more frequent, with much longer and more prolonged droughts expected in the near future. Water scarcity is often a problem in many countries, partly due to the increased population, and also the increased agricultural, energy, and industrial sectors increased demand for water (Bates et al., 2008). The effects of drought can be diverse, significantly reducing agricultural production, increasing forest fires, and jeopardizing adequate quality and quantity of municipal water. This is particularly true in the Mediterranean regions of Europe but also in parts of Central and Eastern Europe (Vogt and Somma, 2000). It is primarily due to its complex properties, as drought tends to develop slowly but may last for months or even years (Wilhite et al., 2007). The drought's effects can affect different sectors in different ways. Its impact on the industry is manifested in terms of water supply. In agriculture, this is mainly reflected in changes in crop yields. It reduces the resistance of plants due to the effect of air on dust concentration. Measuring effective adaptation activities require measurable indicators to monitor changes. In addition, its complexity is reflected in the lack of a unique definition and the variety of indicators used to analyze meteorological, hydrological, and socioeconomic droughts. A timely and comprehensive assessment of vulnerability to drought is a major challenge. Drought is one of the most complex hazards of nature and affects more people than any other hazard (Mishra and Singh, 2011). Although climate forecasts are characterized by a degree of uncertainty, there is a general agreement on the projected increase in extreme events in Europe in the twenty-first century, triggered by the rise in temperature due to global warming (IPCC, 2014, Forzieri et al., 2016). In recent decades, the severity and frequency of droughts in southern Europe have increased in the Mediterranean, especially in the spring and summer. It was also clearly growing in the Carpathian region. On the contrary, in the northern European region, rainfall has increased (Spinoni et al., 2018a and b).

This study focuses on agricultural drought in Hungary. Droughts have been frequent in Hungarian history, resulting in reduced yields, the destruction of livestock, and the threat of hunger and epidemics. The frequency of droughts also increased significantly in Hungary. Hungary has a moderate drought every 2 years and a severe drought every 3 years. They will 
be more frequent due to weather extremes, last longer, become more extensive, and have more severe consequences (Mezősi et al. 2014). The Hungarian government is committed to making Hungary climate neutral by 2050, and this is the ultimate goal of the National Energy and Climate Plan (NEECP, 2020), which was adopted in early 2020. It is also acknowledged that climate change presents a serious risk, and the transition towards more resilient natural and socioeconomic systems is a crucial element of national security.

Recently, county-level climate change strategies have been prepared in Hungary. The strategies have been developed under the assistance and supervision of the Alliance of Climate-Friendly Municipalities and approved by the Assemblies of County's Municipalities. The financial background was provided by the Environmental and Energy Efficiency Operative Programme of Hungary, funded by the EU Cohesion Fund and Regional Development Fund. The NUTS-3-level climate change strategies are entirely consistent with The Second Climate Change Strategy of Hungary, 2020 adopted by the parliament in October 2018. NCCS-2 comprises three sub-documents (sub-strategies) in line with the three pillars of climate policy: the National Decarbonization Roadmap for mitigation, the National Adaptation Strategy for adaptation, and the Climate Change Partnership Plan for awareness-raising.

Taking the National Adaptation Strategy of NCCS2 into account, all county-level strategies shall consist of a comprehensive chapter on impacts and adaptation. The strategic framework of county-level adaptation shall provide vulnerability assessments and the action's planning related to natural disaster management, water and drought management, rural development, heatwave-related health care, energy policy, tourism, and other sectors. The adaptation-related policy planning includes the adaptation target setting and detailed planning of adaptation measures in the level of counties. The strategic objectives and concrete measures related to water and drought management of the NUTS-3-level climate change strategies form the fundamental source of information in our research.

The main aim of the present study is twofold: firstly, assessing the drought-related vulnerability of the Hungarian NUTS-3 units across their agricultural activity and related features and, secondly, providing a qualitative analysis of the county-level policy papers by paying dedicated attention to drought-related goals, actions, and interventions. Consequently, during this study, an indicatorbased assessment framework has been defined and introduced with a particular focus on data availability and potential further applicability. Since the county-level analysis of drought-related vulnerability and policy-oriented complex analysis lacks the literature regarding the Hungarian NUTS-3 level, this paper may widen the existing literature. In order to reach this goal, the present study is organized into four main sections after the Introduction. Firstly, the applied vulnerability analysis framework with the selected indicators and the policy-oriented analysis is introduced. Secondly, the main numerical results with a strong regional focus and analyses can be read. Thirdly, the Discussion includes the limitations and further applicability of the elaborated method. Finally, the Conclusions summarized the main results and recommendations.

\section{Materials and methods}

\subsection{Methodology of vulnerability calculation}

The concept of vulnerability and its practice-oriented presence in international literature has been expanding rapidly (Turner 2016; Ford et al. 2018; Li et al. 2019). Drought-related vulnerability assessments are at the forefront of current studies (Edalat and Stephen 2019; 
Kreibich et al. 2019; Sutanto et al. 2020) since a considerable amount of arable land is facing numerous challenges in terms of changing climatic patterns from all over the world (Zarafshani et al. 2012; Gan et al. 2016; Urquijo et al. 2017; Musolino et al. 2018; Rajesh et al. 2018; Ausseil et al. 2019). Methodologies applied for assessing drought-related vulnerability vary greatly due to the differences regarding the spatial and temporal aim of studies (Murthy et al. 2015; Dumitraşcu et al. 2018; Kamali et al. 2018; Rojas 2018; Ahmadalipour et al. 2019; Kim et al. 2019; Oikonomou et al. 2019; Vieira et al. 2020). The listed papers have all formed the methodology applying in this study by paying attention to their potential applicability on the Hungarian NUTS-3 level.

Based on the main aim of this study, it is suggested that the overall drought-related vulnerability can be determined as the function exposure, sensitivity, and adaptive capacity based on the IPCC (2007) conceptual framework. Although IPCC has changed its paradigm regarding vulnerability assessment by not taking into consideration exposure as an element of vulnerability (Sharma and Ravindranath 2019), the change of local climatic patterns has a crucial role in the agricultural sector; therefore, this component has also been included in the applied methodology.

According to the conceptual framework for climate change impact assessment (Füssel and Klein 2006, EEA 2017), vulnerability combines exposure, sensitivity, and adaptive capacity of the investigated system. Exposure generally represents the characteristics of climate change by using the following formula:

$$
\langle\boldsymbol{E}\rangle(\mathrm{t}, \mathrm{x})=\sum_{i=1}^{n} \varepsilon_{i} \cdot E_{i}(t, x)
$$

where $\mathrm{Ei}=$ time $(t)$ - and space $(s)$-dependent climate change-related indicator, $\varepsilon \mathrm{i}=$ general (time and space independent) weighting factor of ith exposure indicator, and $\langle\boldsymbol{E}\rangle=$ combined (aggregated) time $(t)$ - and space $(s)$-dependent exposure index.

Sensitivity denotes the general interrelations between the exposure and its impacts on a given system. It reveals the system's non-climatic (i.e., physical, natural, geological) characters by using a similar mathematical representation:

$$
\langle\boldsymbol{S}\rangle(t, x)=\sum_{i=1}^{n} \sigma_{i} \cdot S_{i}(t, x)
$$

where $\mathrm{Si}=$ time $(t)$ - and space $(s)$-dependent sensitivity index, $\sigma \mathrm{i}=$ general (time and space independent) weighting factor of ith sensitivity indicator, and $\langle\boldsymbol{S}\rangle=$ combined (aggregated) time $(t)$ - and space $(s)$-dependent sensitivity index.

Adaptive capacity means the overall socioeconomic ability of a system to adjust to climate change or to cope with its consequences by using the following equation:

$$
\langle\boldsymbol{A}\rangle(t, x)=\sum_{i=1}^{n} \alpha_{i} \cdot A_{i}(t, x)
$$

where $\mathrm{Ai}=$ time $(t)$ - and space $(s)$-dependent adaptive capacity index, $\alpha \mathrm{i}=$ general (time and space independent) weighting factor of ith adaptive capacity indicator, and $\langle\boldsymbol{A}\rangle=$ combined (aggregated) time $(t)$ - and space $(s)$-dependent adaptive capacity index. It shall be noted that all of the selected exposure, sensitivity, and adaptive capacity indicators (Ei, $\mathrm{Si}, \mathrm{Ai}$, respectively) shall be normalized in a given range (i.e., from 0 to 1 ). The 
aggregated indices of exposure, sensitivity, and adaptive capacity $(\langle\boldsymbol{E}\rangle,\langle\boldsymbol{S}\rangle$, and $\langle\boldsymbol{A}\rangle$, respectively) shall be transformed to a uniform scale of scores, i.e., from 1 to 5 .

Finally, the vulnerability index may be calculated by the multilinear combination of aggregated exposure, sensitivity, and adaptive capacity indices by using the following formula:

$$
\langle\boldsymbol{D} \boldsymbol{V I}\rangle(t, x)=\langle\boldsymbol{E}\rangle(\mathrm{t}, \mathrm{x}) \cdot\langle\boldsymbol{S}\rangle(t, x) \cdot[6-\langle\boldsymbol{A}\rangle(t, x)]
$$

where $\langle\boldsymbol{D} \boldsymbol{V I}\rangle=$ combined (aggregated) time $(t)$ - and space $(s)$-dependent drought vulnerability index.

In this study, the following basic assumptions were applied:

- The time dependencies were defined as averages of 2021-2050 and 1961-1990 time periods.

- The spatial scale was determined as NUTS-3 level mean values.

- The set of exposure indicators (Ei) were limited to one selected indicator of Pálfai drought index (PaDI).

- The set of sensitivity indicators ( $\mathrm{Si}$ ) were limited to one selected indicator of topsoil sand content.

- The set of adaptive capacity indicators (Ai) were limited to one selected indicator of specific irrigation water use.

- No weighting factors were used.

\subsection{Selection of exposure indicator}

In this study, in parallel with the before-mentioned IPCC nomenclature, exposure refers to the modifying climatic condition over a given area and time. In the current literature dealing with drought-related issues in the Carpathian basin (Mezösi et al. 2014; Fiala et al. 2015; Gulácsi and Kovács 2018a, b), the Pálfai Drought Index (PaDI) is an often-used indicator to reveal seasonal-oriented aridity patterns in a given area. The PaDI can be calculated by using the following equation:

$$
P a D I=\frac{\frac{\left[\sum_{i=a p r}^{a \mathrm{ug}} T_{i}\right]}{500}}{c+\sum_{i=o c t}^{\text {sept }}\left(P_{i} * w_{i}\right)},
$$

where $\mathrm{PaDI}=$ drought index, in ${ }^{\circ} \mathrm{C} / 100 \mathrm{~mm} ; \mathrm{Ti}=$ monthly mean temperature from April to August, in ${ }^{\circ} \mathrm{C} ; \mathrm{P}_{\mathrm{i}}=$ monthly sum of precipitation from October to September, in $\mathrm{mm}$; wi = weighting factor; $\mathrm{c}=$ constant $(10 \mathrm{~mm})$. It can be seen that the strength of drought is defined from year to year; however, the modified PaDI focuses on the severity of droughts for 30 years. The exposure indicator applied in this study is the relative change of PaDI for 2021-2050 based on 1961-1990. Historical data and future projections are available for Hungary via the website $^{1}$ of the National Adaptation Geo-information System (NAGiS), which provides various geoinformation concerning climate adaptation data from different fields. The selection of the 1961-1990 and 2021-2050 periods is based on scientific robustness since these

\footnotetext{
${ }^{1}$ https://nater.mbfsz.gov.hu
} 
timeframes are often studied in the literature with a considerable amount of data regarding different climatic factors. In the case of PaDI, the area of Hungary has been divided into $10 \mathrm{~km} \times 10 \mathrm{~km}$ grids that can be defined as discrete sampling points with a total number of 1103. The relative change of PaDI as our exposure indicator for each NUTS-3 regions was defined as the following:

$$
P a D I_{\text {rel }}=\frac{P a D I_{2021-2050}-P a D I_{1961-1990}}{P a D I_{1961-1990}},
$$

where

$\mathrm{PaDI}_{2021-2050}$ is the average value of PaDI points within the boundary of given regions defined by using outputs of the ALADIN-Climate model from 2021 to 2050; $\mathrm{PaDI}_{1961-1990}$ is the average value of $\mathrm{PaDI}$ points within the boundary of given regions by using historical data from period 1961-1990. Figure 1 indicates the examined NUTS-3 level sampling area.

\subsection{Selection of sensitivity and adaptive capacity indicator}

In the case of sensitivity, in parallel with the IPCC (2007) definition, the main analyzing point refers to the potential impacts of changing climatic patterns from a given perspective. Hereby, topsoil sand content was selected as the sensitivity indicator derived from the NaGIS database covering the same $10 \mathrm{~km} \times 10 \mathrm{~km}$ grids introduced in the case of exposure above. Higher sand content in the top $30-\mathrm{cm}$ soil contributes to reduced water retention capacity and leaking bottle effect since the infiltrated water cannot be accumulated in the soil (Várallyay 2008, 2015). Consequently, as a climate-independent factor, topsoil sand content can describe the weatherrelated activity of the agricultural system, and it can be applied as a sensitivity indicator.

Finally, adaptive capacity as the third component of the drought-related vulnerability of Hungarian NUTS-3 regions was calculated by using statistical data regarding the Hungarian agricultural sector from the Hungarian Central Statistical Office ${ }^{2}$ and the Research Institute of Agricultural Economics. ${ }^{3}$ It shall be emphasized that adaptive capacity in the elaborated assessment system refers to the human-made response to changing climatic patterns instead of the previously introduced exposure and sensitivity concepts. At the beginning of indicator selection, two variables were identified as critical factors in describing adaptive capacity. The first one is the agricultural GDP/ha, which is unavailable directly in the database of the Hungarian Central Statistical Office; consequently, an "index-generation process" has been performed by considering numerous other statistical data. The second indicator concerning adaptive capacity is the amount of irrigation water per hectares derived from the Research Institute of Agricultural Economics database. To reveal the potential duplication between explanatory factors, the Pearson correlation coefficient was calculated by considering all NUTS-3 regions with an $R^{2}=0.773$. The correlation was proved with the calculation of $t$ values; therefore, agricultural GDP/ha as the adaptive capacity indicator was deselected.

The drought vulnerability index is calculated by taking into consideration natural- and nonnatural factors. Natural driving forces are the exposure and the sensitivity, which increase the overall vulnerability of a given area, while adaptive capacity is a nonnatural determinant decreasing the vulnerability index. According to the previously mentioned IPCC conceptual framework, the drought-related vulnerability index can be defined as the multiplication of

\footnotetext{
2 http://www.ksh.hu/stadat_eves_4_1

${ }^{3}$ https://www.naik.hu/dokumentumok
} 


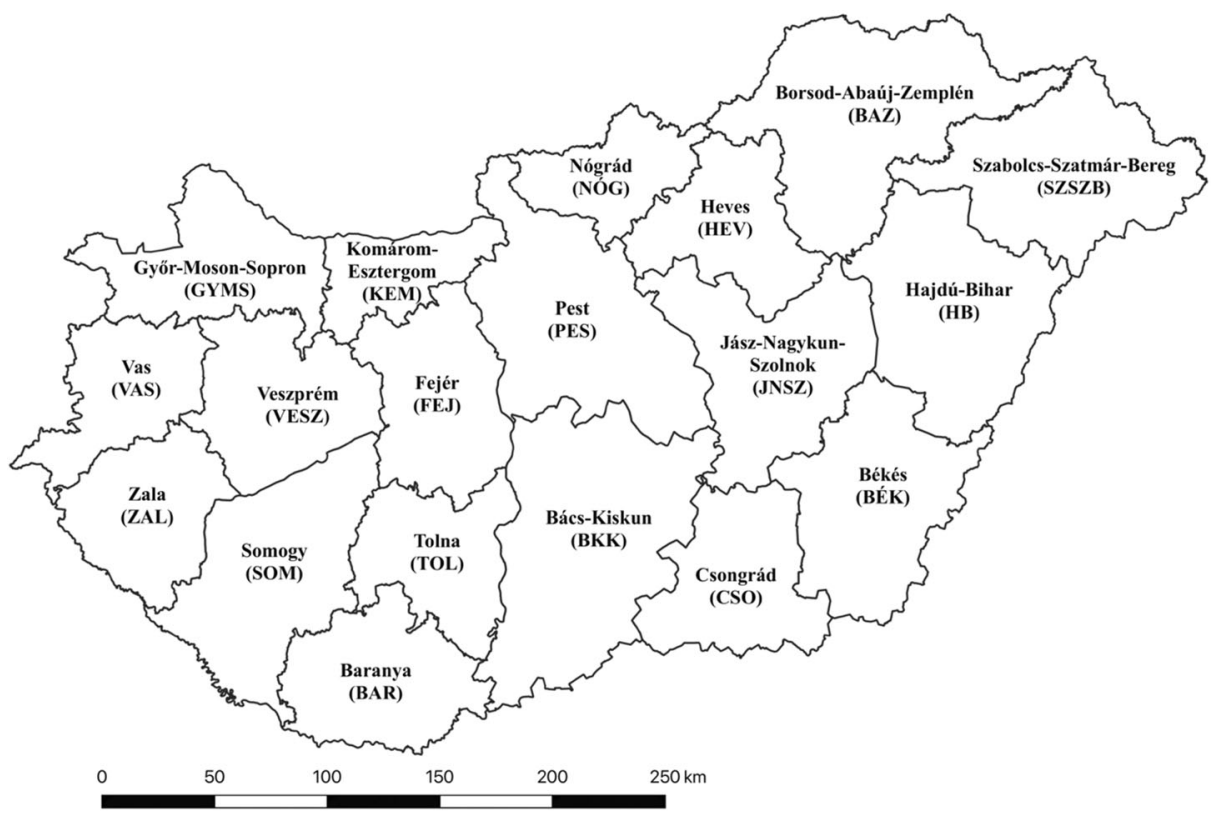

Fig. 1 Study area

exposure, sensitivity, and adaptive capacity; however, the latter is calculated inversely in the equation (see in the Results).

\subsection{Methodology of assessment of drought-related policy performances}

During the research, the DMCSEE (Drought Management Centre for Southeastern Europe) and the DriDanube project were studied, investigating drought-related issues in Southeastern Europe and the Danube Region (DriDanube Manual for drought impacts assessment, 2017). These studies incorporate a broad scale, where the preparation for drought, risk assessment, monitoring, and evaluating are all present. DMCSEE projects contribute to drought preparedness, and it aims to reduce drought impact. The methodology created to measure drought sensitivity in the project consists of forming category maps and calculating drought sensitivity maps. Three necessary parameters were used: slope angle, sunlight duration, and precipitation. Optional parameters were also indicated: surface coverage, soil type, irrigation, and relative groundwater level (Drought Management Centre for South-East Europe - DMCSE, 2012; DRIDANUBE - Drought Risk in the Danube Region, 2017).

In this paper, three indicators regarding exposure, sensitivity, and adaptive capacity were used. It focuses more on a nonnatural factor, the adaptive capacity, which is the irrigation water usage during drought. Irrigation, which is highlighted in the paper, is one of the most crucial drought control methods. Another difference is the areas examined by the different projects. In this paper, the calculations on the NUTS-3 level of the country were applied, which hopefully describes the vulnerability of the counties more precisely.

The assessment framework of drought-related policy performance of NUTS-3 level climate change strategies is based on the calculation of complex environmental (Hsu et al., 2016), sustainable, or climate change performance indices (Burck et al., 2018). A similar 


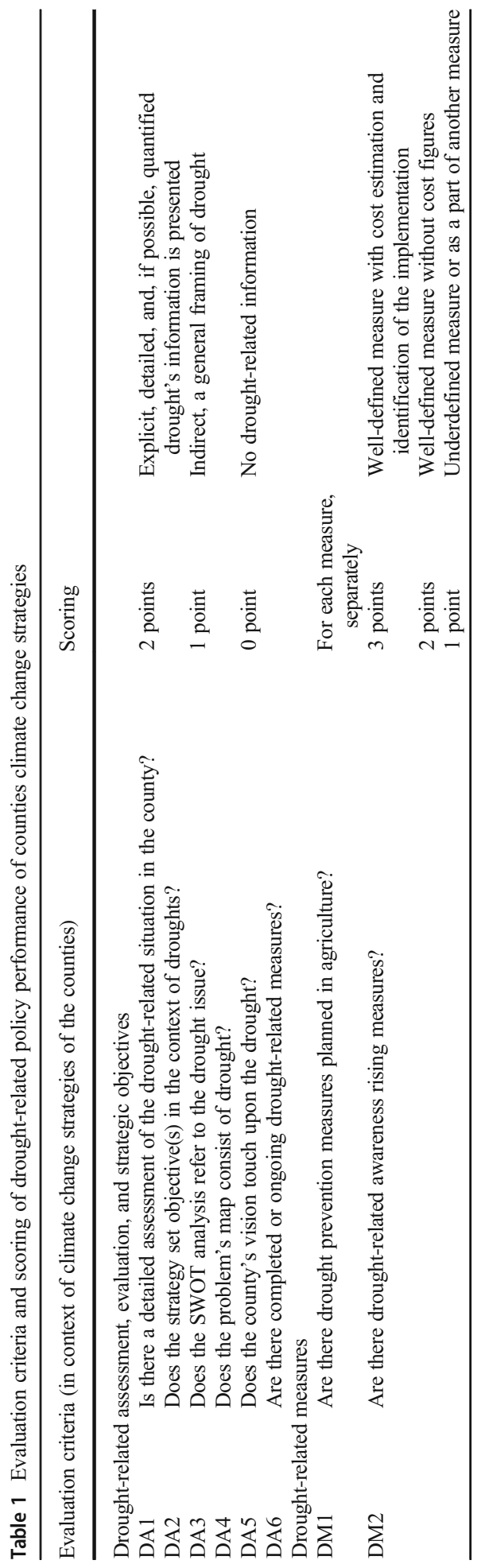


methodology has also been used for numerous strategic environmental assessments (Pálvölgyi, 2010) during in implementation of the SEA directive in Hungary. A specific scorecard has been developed to evaluate the drought-related objectives and measures. The scorecard is based on a set of evaluation criteria, presented in Table 1.

The evaluation was based on a collective assessment made by an expert panel that scored the drought-related evaluation criteria within the drought policies expressed in each county's climate change strategies. The sum of scores characterizes the strategic significance and representation of droughts adequately; therefore, these aggregated values are transformed to a scale of 1 to 5 and identified as the county's drought policy performance index (DPPI).

\section{Results}

The results of the detailed analysis of drought-related vulnerability on the Hungarian NUTS-3 level are introduced in the following paragraphs. Before a detailed introduction of results, it is worth emphasizing that Budapest is managed together with Pest county during the evaluation and county-level calculations due to the almost complete lack of agricultural activity in the capital.

\subsection{Exposure}

Firstly, the results of the exposure indicator are interpreted by using Quantum GIS software and NAGiS online data platform to visualize and calculate the average of relative PaDI. As was mentioned above, relative PaDI shows the change between the strength of droughts regarding the period 1961-1990 and 2021-2050, the latter representing the absolute change of the value based on the first period. For forecasting the future values, climatic data from the ALADIN-Climate model was used by the NAGiS platform, which provides raster- and grid-based maps for further calculations. Figure 2. represents the indicator-building process by adding the two underlying maps considering PaDI conditions in Hungary.

Grid-based data were used to analyze region-specific values considering basic statistical features (see Table 2) and then to categorize the outputs by using quantiles. Clustering the regions contributes to defining an overall exposure value for each of them, which is added to the final calculation to define the drought vulnerability index (DVI) and to visualize the regionbased average of the relative PaDI (see Fig. 3). This methodology provides a range from 1 to 5 to mark each of the regions, where one refers to less-intensive droughts and five is considering in regions with a considerable amount of projected change considering the strength of drought periods.

Using mean values after the statistical analysis of every discrete PaDI points within the boundaries of a given NUTS-3 region, classification can be made by using quantiles to visualize data. Figure 3 represents these clusters and shows thought-provoking results regarding the geographical slope of the change of aridity index as our exposure indicator. According to the historical data, all of the NUTS-3 regions from the Great Plain (southern-eastern regions with a considerable agricultural sector) are marked with red or orange colors. However, the relative change of the strength of projected droughts is less intensive because this value (see the second map of Fig. 2) was moving westward. Thus, southern regions have robust exposure compared to regions from Central and Western Hungary. 


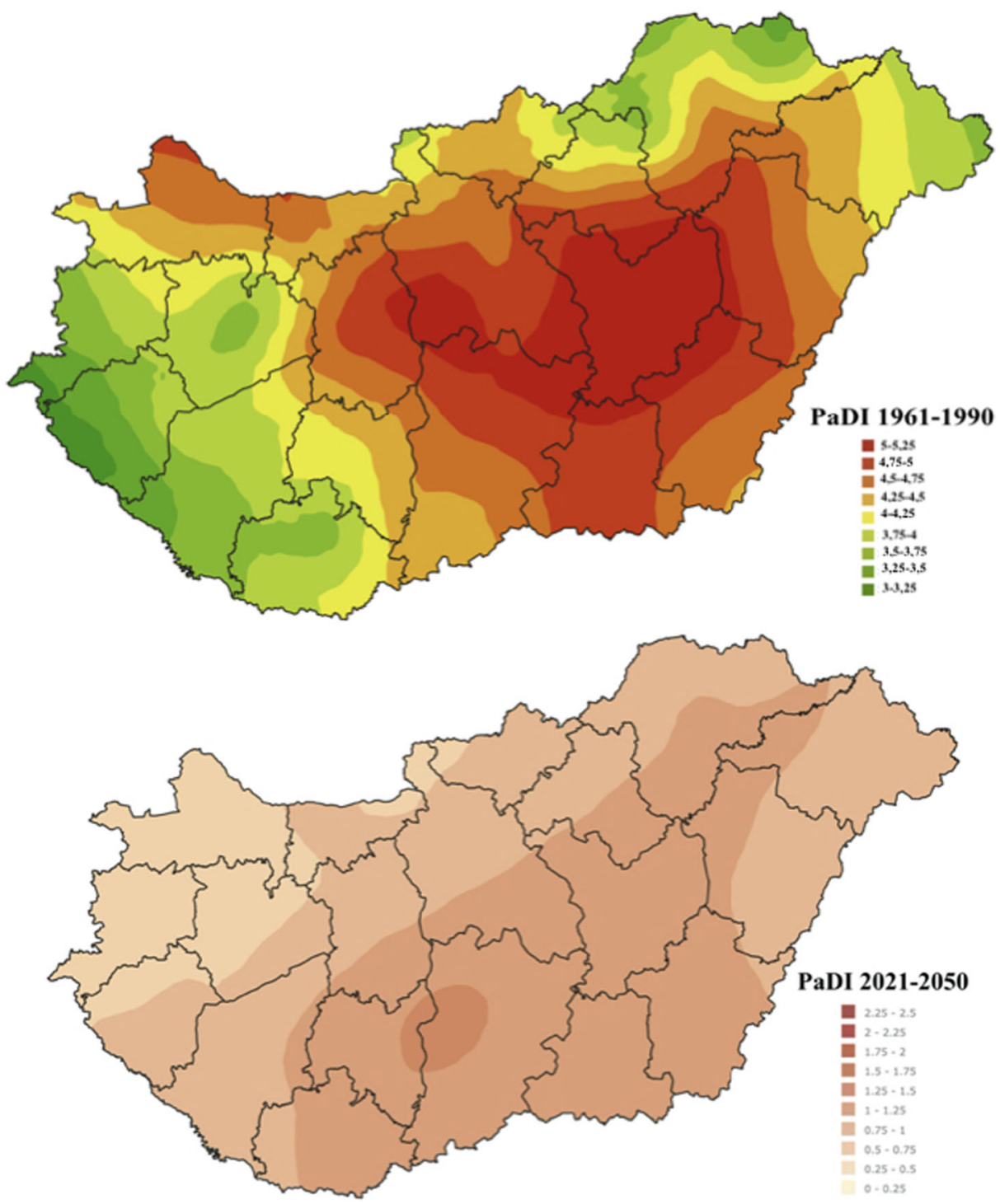

Fig. 2 PaDI values for the period of 1961-1990 and 2021-2050 (absolute change)

\subsection{Sensitivity}

The selected sensitivity indicator is defining the topsoil sand content. According to our presumption, more sand fraction in the topsoil layer leads to higher sensitivity regarding agricultural activity in future droughts based on the reduced water retention capacity. The downloaded raw data concerning the Hungarian NUTS-3 units were restructured and marked with a red-yellow-green scale. The mean value of every NUTS-3 unit was calculated (Table 3) to visualize the results (see Fig. 4). Then, similar to the exposure values, quantiles were formulated based on the outputs of the previously described methodology; thus, spatial patterns of sensitivity can be identified and analyzed. 
Table 2 Statistical features of the exposure indicator (relative PaDI) by NUTS-3 regions

\begin{tabular}{|c|c|c|c|c|c|}
\hline NUTS-3 regions & Mean & Min & Max & St dev & Count \\
\hline Bács-Kiskun & $19.80 \%$ & $16.39 \%$ & $25.81 \%$ & $1.96 \%$ & 99 \\
\hline Baranya & $21.09 \%$ & $16.67 \%$ & $33.34 \%$ & $2.94 \%$ & 54 \\
\hline Békés & $17.62 \%$ & $13.82 \%$ & $20.62 \%$ & $1.59 \%$ & 86 \\
\hline Borsod-Abaúj-Zemplén & $18.14 \%$ & $11.10 \%$ & $34.63 \%$ & $4.37 \%$ & 67 \\
\hline Csongrád & $18.65 \%$ & $16.35 \%$ & $20.63 \%$ & $1.12 \%$ & 48 \\
\hline Fejér & $14.79 \%$ & $9.28 \%$ & $21.18 \%$ & $2.79 \%$ & 47 \\
\hline Győr-Moson-Sopron & $9.81 \%$ & $6.75 \%$ & $12.75 \%$ & $1.14 \%$ & 49 \\
\hline Hajdú-Bihar & $15.42 \%$ & $12.69 \%$ & $20.12 \%$ & $1.74 \%$ & 78 \\
\hline Heves & $16.22 \%$ & $11.71 \%$ & $26.46 \%$ & $2.79 \%$ & 44 \\
\hline Jász-Nagykun-Szolnok & $16.82 \%$ & $14.20 \%$ & $19.67 \%$ & $1.33 \%$ & 68 \\
\hline Komárom-Esztergom & $11.35 \%$ & $9.45 \%$ & $15.00 \%$ & $1.28 \%$ & 28 \\
\hline Nógrád & $12.67 \%$ & $9.40 \%$ & $19.01 \%$ & $2.01 \%$ & 28 \\
\hline Pest & $15.19 \%$ & $7.78 \%$ & $28.03 \%$ & $4.28 \%$ & 83 \\
\hline Somogy & $17.22 \%$ & $12.49 \%$ & $23.68 \%$ & $2.16 \%$ & 70 \\
\hline Szabolcs-Szatmár-Bereg & $16.41 \%$ & $12.30 \%$ & $22.51 \%$ & $2.06 \%$ & 71 \\
\hline Tolna & $21.99 \%$ & $16.62 \%$ & $26.75 \%$ & $2.36 \%$ & 43 \\
\hline Vas & $11.98 \%$ & $8.53 \%$ & $17.06 \%$ & $2.21 \%$ & 42 \\
\hline Veszprém & $12.48 \%$ & $8.52 \%$ & $20.62 \%$ & $2.75 \%$ & 54 \\
\hline Zala & $15.20 \%$ & $10.58 \%$ & $18.78 \%$ & $2.19 \%$ & 44 \\
\hline
\end{tabular}

According to the results, it can be seen that four counties, namely, Bács-Kiskun, Pest, Komárom-Esztergom, and Szabolcs-Szatmár-Bereg, place on the first quantile with more than $45 \%$ topsoil sand content, respectively. However, some potentially arid regions perform much better in the case of sensitivity compared to their exposure-related performance. Such regions are situated in the eastern part of Hungary, while in the western part, numerous counties with less exposure facing a considerably higher amount of sensitivity. It is worth mentioning the selected spatial level mask microscale values of the $10 \mathrm{~km} \times 10 \mathrm{~km}$ raw data, but an almost

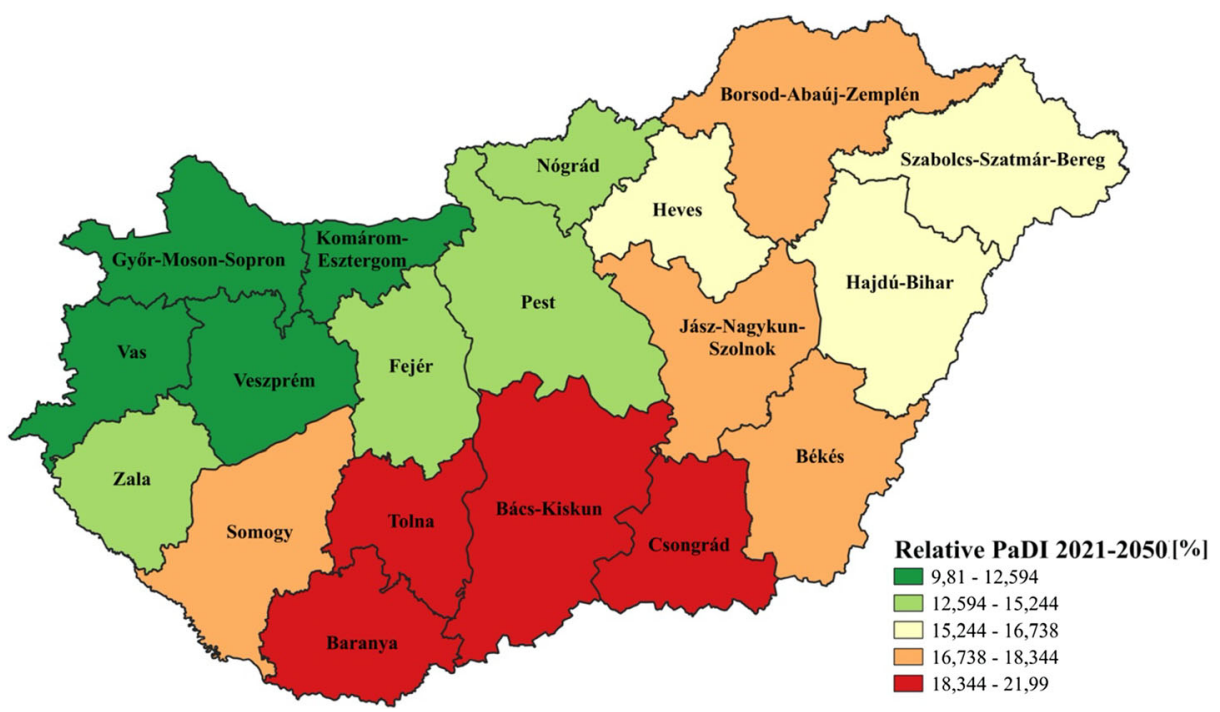

Fig. 3 Exposure indicator (Relative PaDI values) after clustering the NUTS-3 regions 
Table 3 Statistical description of sensitivity values [\%] by NUTS-3 regions

\begin{tabular}{|c|c|c|c|c|c|}
\hline NUTS-3 regions & Mean & Min & Max & St dev & Count \\
\hline Bács-Kiskun & 62.582 & 14 & 94 & 0.013 & 99 \\
\hline Baranya & 19.500 & 9 & 39 & 0.007 & 54 \\
\hline Békés & 16.776 & 7 & 39 & 0.017 & 67 \\
\hline Borsod-Abaúj-Zemplén & 19.233 & 9 & 49 & 0.013 & 86 \\
\hline Csongrád & 41.729 & 11 & 92 & 0.023 & 48 \\
\hline Fejér & 36.830 & 15 & 58 & 0.009 & 47 \\
\hline Győr-Moson-Sopron & 34.122 & 15 & 64 & 0.012 & 49 \\
\hline Hajdú-Bihar & 28.436 & 4 & 91 & 0.020 & 78 \\
\hline Heves & 23.727 & 8 & 55 & 0.016 & 44 \\
\hline Jász-Nagykun-Szolnok & 21.206 & 9 & 54 & 0.020 & 68 \\
\hline Komárom-Esztergom & 49.929 & 26 & 68 & 0.011 & 28 \\
\hline Nógrád & 32.571 & 17 & 60 & 0.010 & 28 \\
\hline Pest & 51.663 & 20 & 92 & 0.016 & 83 \\
\hline Somogy & 39.886 & 16 & 73 & 0.009 & 70 \\
\hline Szabolcs-Szatmár-Bereg & 50.352 & 10 & 91 & 0.022 & 71 \\
\hline Tolna & 28.605 & 10 & 63 & 0.009 & 43 \\
\hline Vas & 31.619 & 14 & 58 & 0.009 & 42 \\
\hline Veszprém & 39.185 & 16 & 64 & 0.010 & 54 \\
\hline Zala & 33.091 & 12 & 59 & 0.009 & 44 \\
\hline
\end{tabular}

clearly identified geographical slope regarding the sensitivity values can be drawn concerning Hungarian NUTS-3 units.

\subsection{Adaptive capacity}

The last component of climate vulnerability in terms of droughts regarding agricultural activity is the adaptive capacity, which is calculated using statistical data of NUTS-3 regions retrieved from the Research Institute of Agricultural Economics. The applied indicator is the irrigation water use per cultivated hectares in $\mathrm{m}^{3}$ calculated for each region, summarized in Table 4. Based on our assumption, more irrigation results in a higher adaptive capacity of an agricultural sector facing severe droughts in the future. Similar to the previously proposed methodology, individual adaptive capacity values were clustered into quantiles to develop an easily understandable figure (Fig. 5) and to determine the adaptive capacity score of counties. According to the results, poor northeastern counties can be described with less adaptive capacity due to the lack of irrigation water usage to reduce the potential impacts of drought. Well-performed regions concentrated around the horizontal corridor of Hungary; moreover, less adaptive regions are situated in the southern and northwestern parts of the country.

Finally, based on the results of exposure, sensitivity, and adaptive capacity, the overall climate vulnerability of NUTS-3 regions regarding potential drought can be determined by using outputs of quantiles for each category. Table 5 summarizes the values of each category determined for each county by applying a range from 1 to 5 .

Figure 6 represents the overall and classified drought-related vulnerability index regarding NUTS-3 regions in Hungary. It can be stated that both the most vulnerable counties are concentrated in an easily identifiable area based on their previously described performance. Vulnerability classification was performed using quantiles in the Quantum GIS platform to divide the counties into equal groups. The most vulnerable counties are situated in the southern part of the country, namely Somogy, Baranya, Csongrád, and Bács-Kiskun, with one 

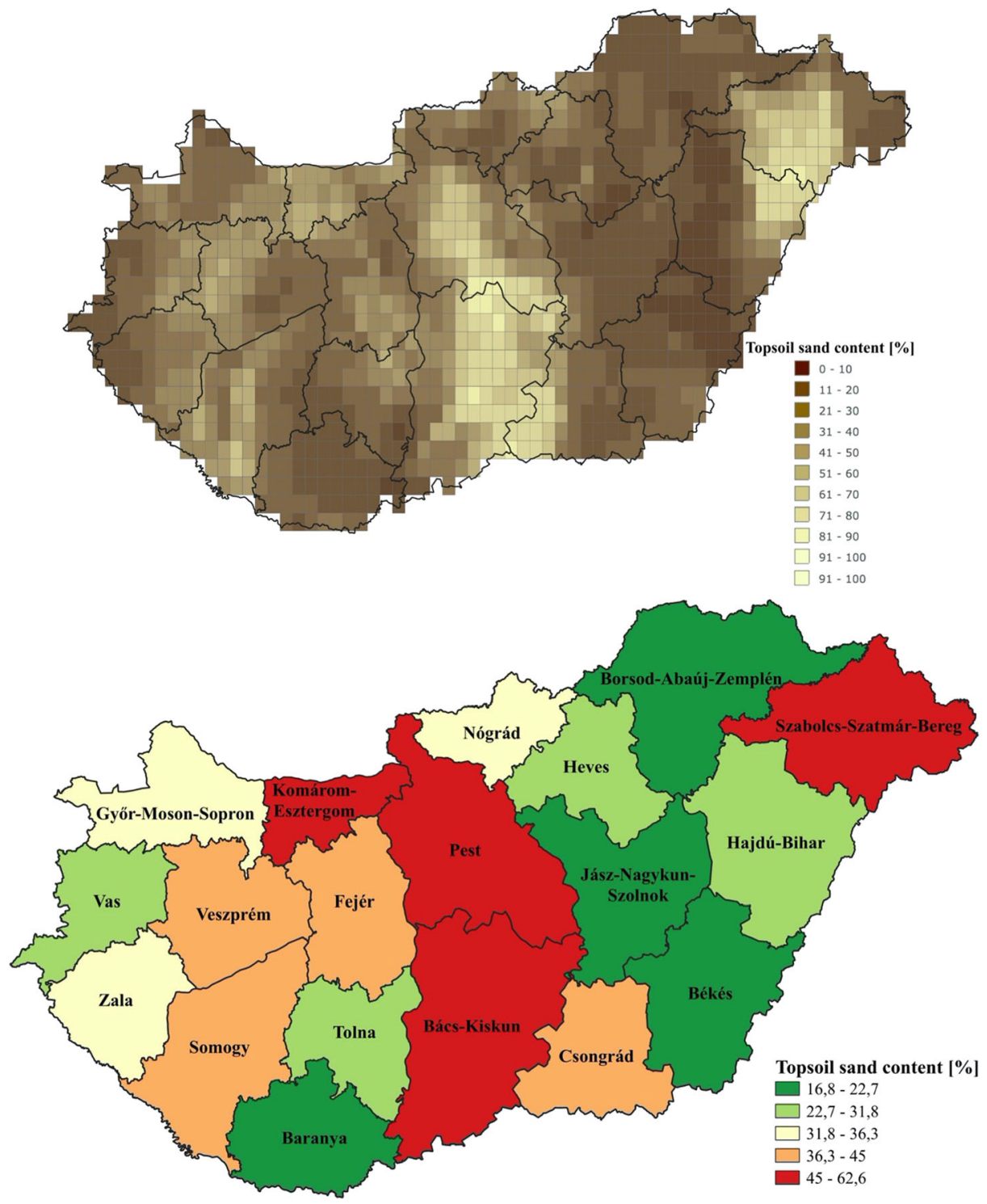

Fig. 4 Input data and counties average values in the case of sensitivity

exception from the southern part, namely Szabolcs-Szatmár-Bereg. Counties with the best performance can be found in the two opposite corners of Hungary: Vas, Veszprém, and Fejér counties from the western part of the country, while Jász-Nagykun-Szolnok, Hajdú-Bihar, and Békés are situated in the southeastern area. Those NUTS-3 regions where adaptive capacity is lacking due to the reduced amount of irrigation, namely Nógrád, Heves, and Tolna, are categorized as moderately vulnerable regions. Counties with an overall slight vulnerability are Zala, Baranya, and Borsod-Abaúj-Zemplén; additionally, Komárom-Esztergom, and Pest can be described counties with moderate resilience. 
Table 4 Values of adaptive capacity by NUTS-3 units

\begin{tabular}{ll}
\hline NUTS-3 regions & Specific irrigation water use $\left(\mathrm{m}^{3}\right) /$ ha $)$ \\
\hline Bács-Kiskun & 1319.86 \\
Baranya & 817.1 \\
Békés & 1584.36 \\
Borsod-Abaúj-Zemplén & 620.62 \\
Csongrád & 1243.75 \\
Fejér & 2892.23 \\
Győr-Moson-Sopron & 887.48 \\
Hajdú-Bihar & 2621.14 \\
Heves & 382.76 \\
Jász-Nagykun-Szolnok & 1972.8 \\
Komárom-Esztergom & 1813.47 \\
Nógrád & 585.9 \\
Pest & 5928.83 \\
Somogy & 1001.42 \\
Szabolcs-Szatmár-Bereg & 711.97 \\
Tolna & 793.35 \\
Vas & 1543.27 \\
Veszprém & 1790.39 \\
Zala & 1621.28 \\
\hline
\end{tabular}

Finally, the spatial disparities in the county's drought-related policy planning are examined. Figure 7 shows the interrelations of the drought vulnerability index (DVI) and the drought prevention policy index (DPPI) presented above.

As it is shown, the counties were clustered into four types as follows:

- Type A. "Alerts"-These counties (Heves [HEV], Tolna [TOL], Nógrád [NÓG]) can be attributed to relatively high vulnerability and moderate preparedness for droughts. The mentioned counties are among the less developed regions in Hungary, with a relatively

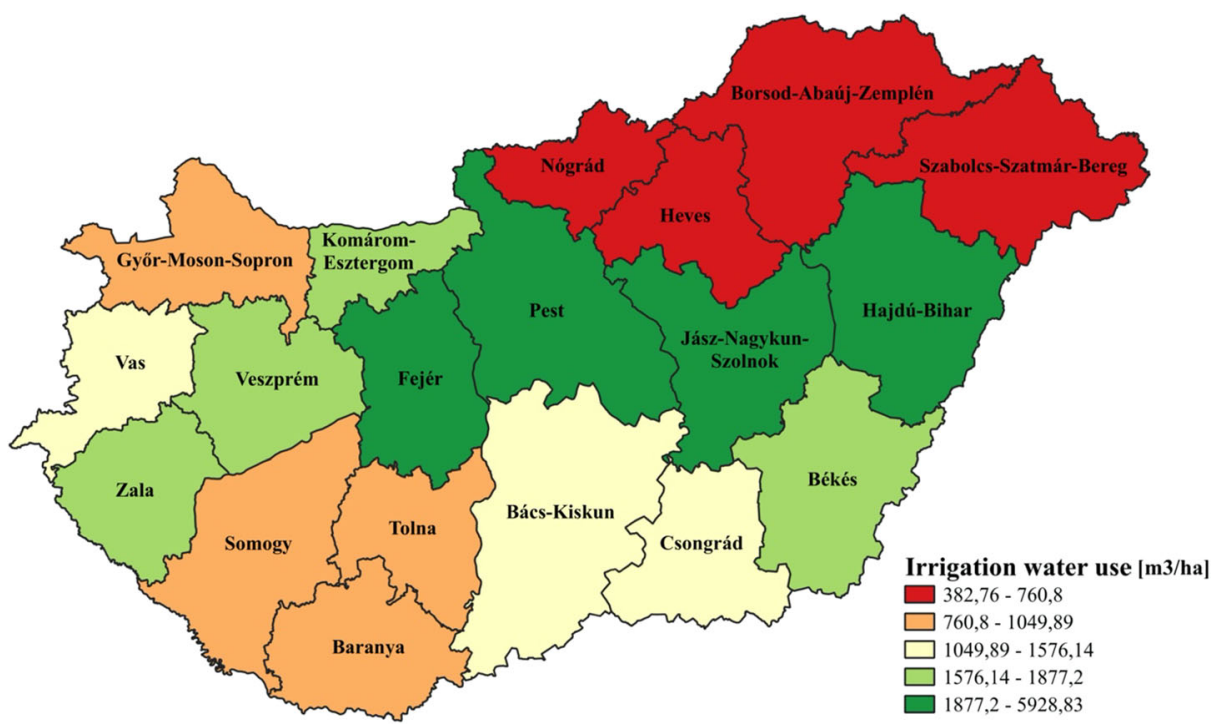

Fig. 5 The drought-related adaptive capacity of NUTS-3 regions 
Table 5 Overall drought vulnerability index (DVI) by counties

\begin{tabular}{|c|c|c|c|c|}
\hline NUTS-3 regions & $\begin{array}{l}\text { Exposure } \\
\text { Classified }\end{array}$ & $\begin{array}{l}\text { Sensitivity } \\
\text { values }\end{array}$ & Adapt. cap. & DVI \\
\hline Bács-Kiskun & 5 & 5 & 3 & 75 \\
\hline Baranya & 5 & 1 & 2 & 20 \\
\hline Békés & 4 & 1 & 4 & 8 \\
\hline Borsod-Abaúj-Zemplén & 4 & 1 & 1 & 20 \\
\hline Csongrád & 5 & 4 & 3 & 60 \\
\hline Fejér & 2 & 4 & 5 & 8 \\
\hline Győr-Moson-Sopron & 1 & 3 & 2 & 12 \\
\hline Hajdú-Bihar & 3 & 2 & 5 & 6 \\
\hline Heves & 3 & 2 & 1 & 30 \\
\hline Jász-Nagykun-Szolnok & 4 & 1 & 5 & 4 \\
\hline Komárom-Esztergom & 1 & 5 & 4 & 10 \\
\hline Nógrád & 2 & 3 & 1 & 30 \\
\hline Pest & 2 & 5 & 5 & 10 \\
\hline Somogy & 4 & 4 & 2 & 64 \\
\hline Szabolcs-Szatmár-Bereg & 3 & 5 & 1 & 75 \\
\hline Tolna & 5 & 2 & 2 & 40 \\
\hline Vas & 1 & 2 & 3 & 6 \\
\hline Veszprém & 1 & 4 & 4 & 8 \\
\hline Zala & 2 & 3 & 4 & 12 \\
\hline
\end{tabular}

low share of agriculture in local economies. It is revealed that their strategies have not adequately reflected the complex natural and socioeconomic risks of drought. During the revision of climate change strategies of these counties, it is recommended to strengthen the drought-related objectives and measures in these counties.

- Type B. "Forward planners"-Csongrád [CSO], Szabolcs-Szatmár-Bereg [SZSZB], Bács-Kiskun [BKK], and Somogy [SOM] counties have robust drought

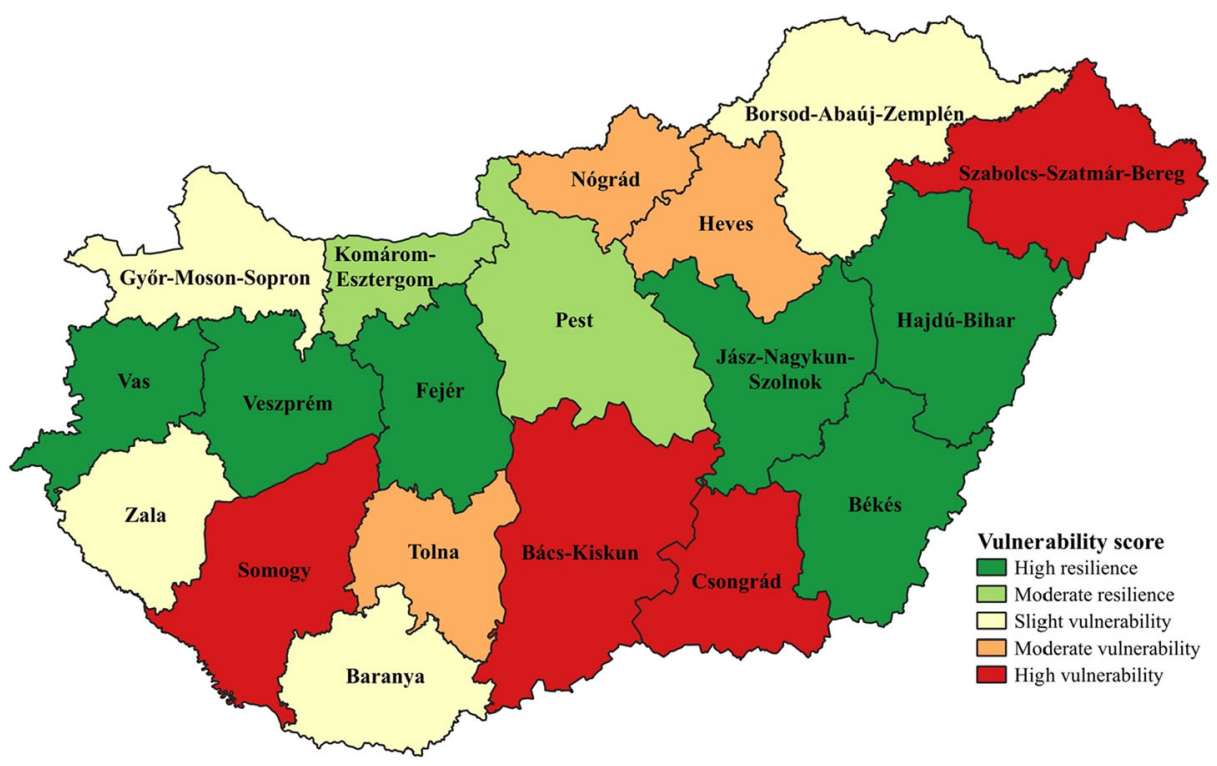

Fig. 6 The overall drought-related vulnerability of NUTS-3 regions in Hungary 


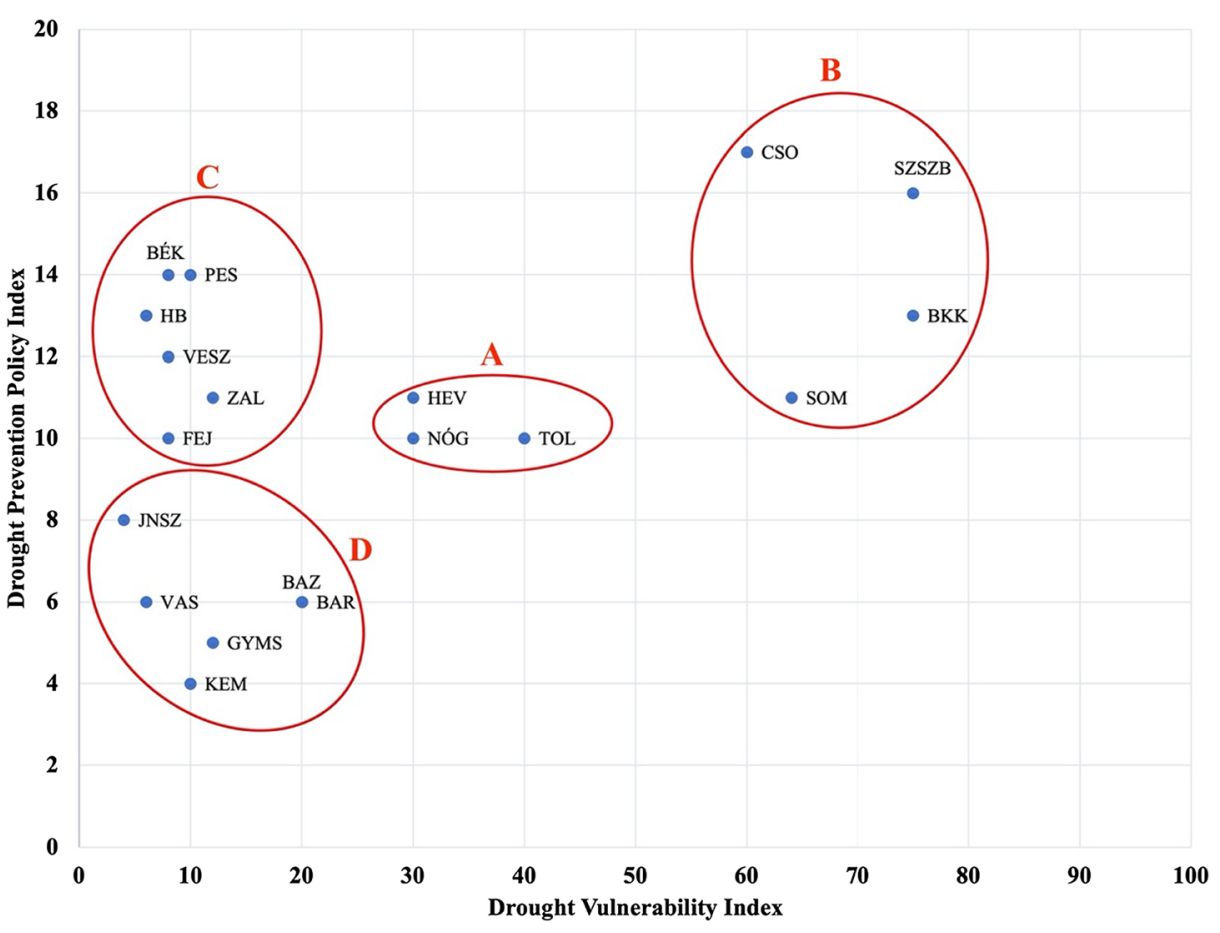

Fig. 7 Relationship between the county's drought-related vulnerability and policy performance

policies, while their vulnerability is on the top quartile. Csongrád és BácsKiskun counties are already suffering from drought's impact on agriculture; therefore, their policy priorities in drought prevention are well-established. Szabolcs-Szatmár-Bereg county (in northeast Hungary) is recently seized by drought phenomena. In particular, this county's strategy considers the drought in a typical forward-looking response.

- Type C. "Overestimates"-Numerous counties (Pest [PEST], Békés [BÉK], Hajdú-Bihar [HB], Veszprém [VESZ], Zala [ZAL], and Fejér [FEJ]) have low vulnerability with a strong emphasis on drought prevention. Typical strategic planning overshot is presented in Pest, Fejér, and Veszprém counties with relatively high economic performances based on growing industry and services. It is concluded that drought prevention's resources might partially be reallocated to other mitigation or adaptation measures.

- Type D. "Neutrals"-Certain county's (Jász-Nagykun-Szolnok [JNSZ], Vas [VAS], GyörMoson-Sopron [GYMS], Borsod-Abaúj-Zemplén [BAZ], Baranya [BAR] and KomáromEsztergom [KEM]) strategies adequately reflect the relatively low drought-related vulnerability with less importance of the relevant policy responses. No further revisions are needed in these cases.

\section{Discussion}

This study has several limitations during selecting indicators, elaborating methodology, and providing outcomes. Firstly, as in many cases founded in the literature, indicator selection is a 
highly relevant quantitative methodology issue. The exposure indicator hereby is the absolute change of $\mathrm{PaDI}$, which is based on temperature and precipitation anomalies, comparing 20212050 values to $1961-1990$ baseline. The current value of $\mathrm{PaDI}$ is missing from the elaborated methodology since the most crucial driving force of selecting exposure timeframe is the scientific robustness. Since data regarding the early 2000s is not available in a public database, this period has not been studied. The sensitivity indicator reflects topsoil sand content as a climate-independent value connected with the selected system's internal feature. Other relevant indicators can be found in the current literature; however, availability as a secondary issue regarding indicator selection has reduced the options. Adaptive capacity is defined as a humanmade response to changing climatic patterns in this study; consequently, the selected indicator, namely the irrigation water use, reflects that feedback. However, it cannot be stated that more irrigation contributes to a sustainable agricultural sector in Hungary since negative lock-ins can be found in this case through unsustainable water management issues. Therefore it must be emphasized that a robust sustainability-based assessment report shall be developed before introducing any new measures to increase the adaptive capacity. Thus, irrigation water use provides a snapshot of current human responses to drought risk in Hungarian counties.

Secondly, it shall be emphasized that this study provides an assessment framework to assess county-level drought vulnerability, which means that indicators for further studies on different spatial units can be modified or more values can be added. The NUTS-3 units seem to be a case study since the main novelty of the elaborated methodology is based on the spatial aggregation of available data with additional policy-oriented analysis. Moreover, it shall be stated that natural processes, such as drought, do not respect nonnatural boundaries; however, the NUTS-3 units as case studies can reveal the regional differences of a climate-related risk by using aggregated spatial patterns.

Finally, applying composite indicators often hidden background patterns of highly complex issues, such as drought vulnerability (Waseem et al. 2015; Bachmair et al. 2016; Liu et al. 2020), especially in aggregated spatial units. As was stated above, this study provides a framework for evaluating drought-related vulnerability and policy readiness of selected NUTS-3 units; therefore, easy-to-use indicators and composite values have to be applied for reaching this goal. The indicators applied in the study can be changed; however, it can be proved that applying a limited number of variables can contribute to providing an overview of a complex problem for policy-makers and decision-makers before developing a more related assessment of the selected issues.

\section{Conclusions}

The purpose of the study was to determine how vulnerable each county is to the expected effects of drought. This paper developed an indicator that categorizes the Hungarian counties based on their drought-related exposure, sensitivity, and adaptability. The exposure indicator (relative PaDI) interpreted was obtained using the Quantum GIS software and NAGiS online data platform, while the sensitivity indicator reflects topsoil sand content. The last component, adaptive capacity, was calculated by using statistical data of NUTS-3 regions retrieved from the Research Institute of Agricultural Economics. The adaptive capacity indicator shows the irrigation water use per hectares in $\mathrm{m}^{3}$.

Based on the results of exposure, sensitivity, and adaptive capacity, the overall climate vulnerability of NUTS-3 regions regarding potential drought was determined by using outputs 
of quantiles for each category. Vulnerability classification was performed by using the Jenks natural break method to divide the counties into equal groups.

According to the relationship between the county's drought-related vulnerability and policy performance, the counties were classified into four types. Type A "alerts" counties have the highest vulnerability and are poorly prepared for droughts compared to other counties. In case of a revision of their climate strategies, it is highly recommended to strengthen the droughtrelated objectives and measures in these counties. Type B "forward planners" have high vulnerability and robust drought policies, which indicates that their drought prevention policy is already well-established. Type C "overestimates" have a low vulnerability but a strong emphasis on drought prevention. Significant drought-related risks are not expected to occur in these counties, so the partial reallocation of drought prevention resources is suggested. Type D "neutrals" respond properly to the relatively low drought-related risks. Their policy is adequate; no further action has to be taken currently.

The study reveals that several counties are paying close attention to reducing the possible drought-related damage. However, there are still a few counties that have not fully realized the potential risks. The results of this study can be used to further increase the adaptation to drought in Hungary, where it is required the most.

Acknowledgements The research reported in this paper and carried out at the Budapest University of Technology and Economics was supported by the "TKP2020, Institutional Excellence Program" of the National Research, Development and Innovation Office in the field of Water Sciences \& Disaster Prevention (BME IEVIZ TKP2020).

Funding Open access funding provided by Budapest University of Technology and Economics.

\section{Declarations}

Conflict of interest The author declares no competing interests.

Open Access This article is licensed under a Creative Commons Attribution 4.0 International License, which permits use, sharing, adaptation, distribution and reproduction in any medium or format, as long as you give appropriate credit to the original author(s) and the source, provide a link to the Creative Commons licence, and indicate if changes were made. The images or other third party material in this article are included in the article's Creative Commons licence, unless indicated otherwise in a credit line to the material. If material is not included in the article's Creative Commons licence and your intended use is not permitted by statutory regulation or exceeds the permitted use, you will need to obtain permission directly from the copyright holder. To view a copy of this licence, visit http://creativecommons.org/licenses/by/4.0/.

\section{References}

Ahmadalipour A, Moradkhani H, Castelletti A, Magliocca N (2019) Future drought risk in Africa: integrating vulnerability, climate change, and population growth. Sci Total Environ 662:672-686. https://doi.org/10. 1016/j.scitotenv.2019.01.278

Aussie AGE, Daigneault AJ, Frame B, Teixeira EI (2019) Towards an integrated assessment of climate and socio-economic change impacts and implications in New Zealand. Environ Model Softw 119:1-20. https:// doi.org/10.1016/j.envsoft.2019.05.009

Bates BC, Kundzewicz ZW, Wu S, Palutikof S (eds) (2008) Climate change and water. Technical Paper of the Intergovernmental Panel on Climate Change, IPCC Secretariat, Geneva, $210 \mathrm{pp}$ 
Burck J, Marten F, Bals C, Hohne N (2018) Climate change performance index results 2018. Climate Action Network, Germanwatch, NewClimate Institute, pp 1-13 Retrieved from https:/germanwatch.org/sites/ default/files/publication/20504.pdf

DRIDANUBE - Drought Risk in the Danube Region (2017) http://www.interreg-danube.eu/approved-projects/ dridanube Accessed 25 November 2020

DriDanube Manual for drought impacts assessment (2017) http://www.interreg-danube.eu/uploads/media/ approved_project_output/0001/38/9810d453460f3867b6bfa38018494315f83e5932.pdf Accessed 25 November 2020

Drought Management Centre for South-East Europe - DMCSEE: (2012) https://www.met.hu/doc/DMCSEE/ DMCSEE_final_publication.pdf Accessed 25 November 2020

Dumitrașcu M, Mocanu I, Mitrică B, Dragotă C, Grigorescu I, Dumitrică C (2018) The assessment of socioeconomic vulnerability to drought in southern Romania (Oltenia plain). Int J Disaster Risk Reduct 27:142154. https://doi.org/10.1016/j.ijdrr.2017.09.049

Edalat MM, Stephen H (2019) Socio-economic drought assessment in Lake Mead, USA, based on a multivariate standardized water-scarcity index. Hydrol Sci J 64:555-569. https://doi.org/10.1080/02626667.2019. 1593988

EEA, 2017. Climate change, impacts and vulnerability in Europe 2016. An indicator-based report. European Environment Agency, Luxembourg: Publications Office of the European Union, 2017 ISBN 978-92-9213835-6, doi:https://doi.org/10.2800/534806

Fiala K, Blanka V, Ladányi Z, Szilassi P, Benyhe B, Dolinaj D, Pálfai I (2015) Drought severity and its effect on agricultural production in the Hungarian-Serbian cross-border area. J Environ Geogr 7:43-51. https://doi. org/10.2478/jengeo-2014-0011

Ford JD, Pearce T, McDowell G, Berrang-Ford L, Sayles JS, Belfer E (2018) Vulnerability and its discontents: the past, present, and future of climate change vulnerability research. Clim Chang 151:189-203. https://doi. org/10.1007/s10584-018-2304-1

Forzieri G, Feyen L, Russo S, Vousdoukas M, Alfieri L, Outten S, Migliavacca M, Bianchi A, Rojas R, Cid A (2016) Multi-hazard assessment in Europe under climate change. Clim Chang 137:105-119. https://doi.org/ 10.1007/s10584-016-1661-x

Füssel HM, Klein RJT (2006) Climate change vulnerability assessments: an evolution of conceptual thinking. Clim Chang 75:301-329. https://doi.org/10.1007/s10584-006-0329-3

Gan TY, Ito M, Hülsmann S, Qin X, Lu XX, Liong SY, Rutschman P, Disse M, Koivusalo H (2016) Possible climate change/variability and human impacts, the vulnerability of drought-prone regions, water resources and capacity building for Africa. Hydrol Sci J 61:1209-1226. https://doi.org/10.1080/02626667.2015. 1057143

Gulácsi A, Kovács F (2018a) Drought monitoring of forest vegetation using MODIS-based normalized difference drought index in Hungary. Hungarian Geogr Bull 67:29-42. https://doi.org/10.15201/hungeobull.67.1. 3

Gulácsi A, Kovács F (2018b) Drought monitoring with spectral indices calculated from Modis satellite images in Hungary. J Environ Geogr 8:11-20. https://doi.org/10.1515/jengeo-2015-0008

IPCC. 2014. Climate Change 2013: The Physical Science Basis. Contribution of Working Group I to the Fifth Assessment Report of the Intergovernmental Panel on Climate Change. In, Stocker TF, Qin D, Plattner GK, Tignor M, Allen SK, Boschung J, Nauels A, Xia Y, Bex V, Midgley PM (eds). Cambridge University Press: Cambridge, UK and New York, NY, 1535 pp.

Kamali B, Abbaspour KC, Wehrli B, Yang H (2018) Drought vulnerability assessment of maize in sub-Saharan Africa: insights from physical and social perspectives. Glob Planet Change 162:266-274. https://doi.org/10. 1016/j.gloplacha.2018.01.011

Kim JS, Jain S, Lee JH, Chen H, Park SY (2019) Quantitative vulnerability assessment of water quality to extreme drought in a changing climate. Ecol Indic 103:688-697. https://doi.org/10.1016/j.ecolind.2019.04. 052

Kreibich H, Blauhut V, Aerts JCJH, Bouwer LM, van Lanen HAJ, Mejia A, Mens M, van Loon AF (2019) How to improve attribution of changes in drought and flood impacts. Hydrol Sci J 64:1-18. https://doi.org/10. 1080/02626667.2018.1558367

Li L, Cao R, Wei K, Wang W, Chen L (2019) Adapting climate change challenge: a new vulnerability assessment framework from the global perspective. J Clean Prod 217:216-224. https://doi.org/10.1016/j. jclepro.2019.01.162

Mezősi G, Bata T, Meyer BC, Blanka V, Ladányi Z (2014) Climate change impacts on environmental hazards on the great Hungarian plain, Carpathian basin. Int J Disaster Risk Sci 5:136-146. https://doi.org/10.1007/ s13753-014-0016-3

Mishra AK, Singh VP (2011) Drought modeling - a review. J Hydrol 403:157-175. https://doi.org/10.1016/j. jhydrol.2011.03.049 
Murthy CS, Laxman B, Sesha Sai MVR (2015) Geospatial analysis of agricultural drought vulnerability using a composite index based on exposure, sensitivity and adaptive capacity. Int J Disaster Risk Reduct 12:163171. https://doi.org/10.1016/j.ijdrr.2015.01.004

Musolino DA, Massarutto A, de Carli A (2018) Does drought always cause economic losses in agriculture? An empirical investigation on the distributive effects of drought events in some areas of Southern Europe. Sci Total Environ 633:1560-1570. https://doi.org/10.1016/j.scitotenv.2018.02.308

NEECP, 2020: National Energy and Climate Plan of Hungary, 2019. Draft version, online available: https://ec. europa.eu/energy/sites/ener/files/documents/ec courtesy translation hu necp.pdf

Oikonomou PD, Tsesmelis DE, Waskom RM, Grigg NS, Karavitis CA (2019) Enhancing the standardized drought vulnerability index by integrating spatiotemporal information from satellite and in situ data. J Hydrol 569:265-277. https://doi.org/10.1016/j.jhydrol.2018.11.058

Pálvölgyi T (2010) A klímaváltozás figyelembevétele a környezeti értékelésekben (Considering climate change in the process of environmental evaluation). "Klíma-21" Füzetek (62):81-87

Rajesh S, Jain S, Sharma P (2018) Inherent vulnerability assessment of rural households based on socioeconomic indicators using categorical principal component analysis: a case study of Kimsar region, Uttarakhand. Ecol Indic 85:93-104. https://doi.org/10.1016/j.ecolind.2017.10.014

Rojas O (2018) Agricultural extreme drought assessment at the global level using the FAO-agricultural stress index system (ASIS). Weather Clim Extrem 100184:100184. https://doi.org/10.1016/j.wace.2018.09.001

Sharma J, Ravindranath NH (2019) Applying IPCC 2014 framework for hazard-specific vulnerability assessment under climate change. Environ Res Commun 1:051004. https://doi.org/10.1088/2515-7620/ab24ed

Spinoni J, Vogt JV, Barbosa P, Dosio A, McCormick N, Bigano A, Füssel HM (2018a) Changes of heating and cooling degree-days in Europe from 1981 to 2100. Int J Climatol 38:e191-e208. https://doi.org/10.1002/joc. 5362

Spinoni J, Vogt JV, Naumann G, Barbosa P, Dosio A (2018b) Will drought events become more frequent and severe in Europe? Int J Climatol 38:1718-1736. https://doi.org/10.1002/joc.5291

Sutanto SJ, Vitolo C, Di Napoli C et al (2020) Heatwaves, droughts, and fires: exploring compound and cascading dry hazards at the pan-European scale. Environ Int 134:105276. https://doi.org/10.1016/j.envint. 2019.105276

The Second Climate Change Strategy of Hungary. Online available: http://nakfo.mbfsz.gov.hu/sites/default/files/ files/N\%C3\%89S_Ogy\%20\%C3\%A1ltal\%20elfogadott.PDF Accessed 12 January 2020

Turner MD (2016) Climate vulnerability as a relational concept. Geoforum 68:29-38. https://doi.org/10.1016/j. geoforum.2015.11.006

Urquijo J, Pereira D, Dias S, De Stefano L (2017) A methodology to assess drought management as applied to six European case studies. Int J Water Resour Dev 33:246-269. https://doi.org/10.1080/07900627.2016. 1174106

Vieira RM da SP, Sestini MF, Tomasella J et al (2020) Characterizing spatio-temporal patterns of social vulnerability to droughts, degradation and desertification in the Brazilian northeast. Environ Sustain Indic 5:100016. https://doi.org/10.1016/j.indic.2019.100016

Vogt JV, Somma F (eds). 2000. Drought and drought mitigation in Europe. Advances in natural and technological hazards research, Vol. 14. Kluwer Academic Publishers: Dordrecht, Netherlands; Boston, MA and London, 336

Wilhite DA, Svoboda MD, Hayes MJ (2007) Understanding the complex impacts of drought: a key to enhancing drought mitigation and preparedness. Water Resour Manag 21:763-774. https://doi.org/10.1007/s11269006-9076-5

Zarafshani K, Sharafi L, Azadi H, Hosseininia G, de Maeyer P, Witlox F (2012) Drought vulnerability assessment: the case of wheat farmers in Western Iran. Glob Planet Change 98-99:122-130. https://oi. org/10.1016/j.gloplacha.2012.08.012

Publisher's note Springer Nature remains neutral with regard to jurisdictional claims in published maps and institutional affiliations. 